\title{
Critique of Auguste Comte's ideology on the death of religion
}

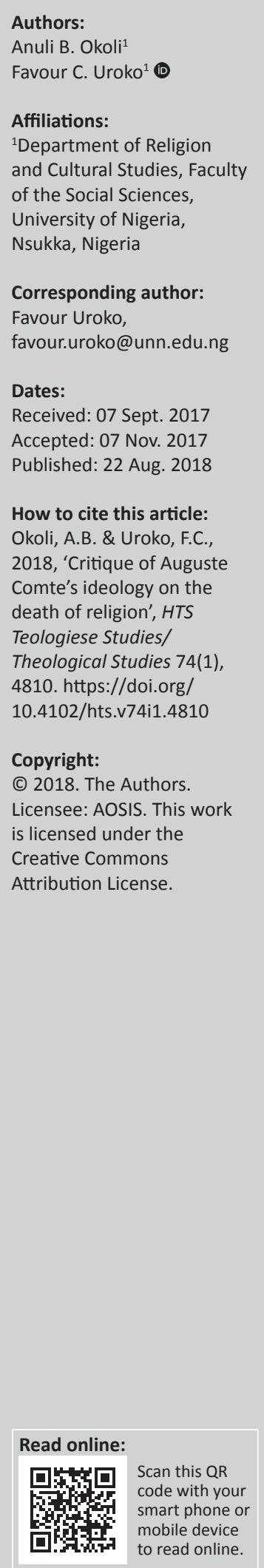

Authors:

Affiliations: and Cultural Studies, Faculty of the Social Sciences, University of Nigeria,

Corresponding author: Favour Uroko,

Dates: Accepted: 07 Nov. 2017

How to cite this article: Okoli, A.B. \& Uroko, F.C. 2018, 'Critique of Auguste Teologiese Studies/ Theological Studies 74(1), 4810. https://doi.org/ Copyright:

(c) 2018. The Authors. is licensed under the Creative Commons Attribution License. mobile device to read onlin
Secularism dealt with the known, whereas religion dealt with the unknown. The rise of secularism threatened the survival of religion. This was the thesis of Auguste Comte. He said there would be a time when the irrelevant nature and death of religion would be recorded. At this point, man would have been able to unravel most of the unknown around him, hence no need for religion. The article has as its aim to examine the flaws in Auguste Comte's ideology on the existence of religion and secularism together. Using the descriptive phenomenological method of research, which allows for an objective analysis of the problem, it was discovered that, notwithstanding Comte's theory, religion and secularism have continued to exist side by side since the 20th century to the contemporary 21st century because they are complementary. It was also discovered that religion exerts a force that cannot be silenced by an industrial revolution of the world. Religion provides the solution to man's innermost needs which cannot be threatened with the rise of secularism.

\section{Introduction}

The inevitability of humanity's dependence on the Supreme-Being has in recent times attracted scientific opinions and thesis. Humanity in his effort to find protection from the forces that he feels control his daily activities and in the midst of the daily challenges and dangers posed by his fellow beings as well as inanimate beings, resorts to veneration and humility to the being which he projects as being supreme to him, seeking protection. Hence, Feuerbach explains that religion is the outward projection of the inward nature of humans, the feeling or consciousness of humanity that he does not and cannot exist apart from a being that is distinct from himself that he does not have himself to thank for his own existence (Loos 2004). This phenomenon has been sketched as the origin of religion and the origin of humanity's subjection to certain unseen powers, which makes humanity see the hand of the Supreme-Being in results they see from any action they take. Religion 'has held sway since the 19th century' (Bergunder 2014:258) and has come to be seen as modern basic belief and idea.

With regard to the meaning of religion, Crabtree (2016) sees it as shared collections of transcendental beliefs that have been passed on from believers to converts that are held by adherents to be actively meaningful and serious. Religion deals with a belief in God or gods and other spiritual or transcendental beings. In order to understand the religion of people, Mbiti (1969:29) explains that people's 'proverbs, short statements, songs, prayers, names, myths, stories and religious ceremonies' embed religious features. Furthermore, Bruce (1996) mentions that religion consists of beliefs, actions and institutions which assume the existence of supernatural entities with powers of action, or impersonal powers or processes possessed of moral purpose. In the context of this article, religion is humanity's recognition of supernatural realities, and the safety and joy humanity derives by worshipping these realities.

This degree of the religiosity of human creatures has been questioned in recent times. This is in view of the activities that have besieged this practice. People no more feel subordinated to the Supreme-Being with regard to certain aspects of their lives such as health, finance, politics and education, among others. Human beings feel that they have attained the powers needed to be safe; these accomplishments were all brought about by globalisation and modernisation, which in both the short run and the long run have brought about a secularised religiosphere in the contemporary world. The sacred has been postulated and viewed with a lesser level of recognition and veneration. August Comte, a renowned French philosopher, explained this phenomenon on the secularisation of the sacred in a model, which he proves as the reason for this development. Comte (1896:476) puts three stages in his model, and in the third stage, he projects a secularised religion void of a high allegiance to the supremacy of the supreme. However, his thesis has been duly countered in recent researches carried out by scholars such as Casanova (1994). This article 
examines how possible it is for religion to survive in the midst of the progress of secularism, taking the views of Auguste Comte as a benchmark. The methodology adopted for this research was the descriptive phenomenological method of qualitative research. This method was so utilised because the data on the ground explains observable manifestations. This study examines how secularisation would be made advantageous to the survival of religion. It looks at modalities that secularisation projects which are very paramount to the continued existence of the sacred (religion).

\section{Statement of the problem}

Several researchers have been able to prove that religion is needed by humans to survive on earth. Elizabeth Nottingham (1968) in her book Religion and Society says that religion is a cultural tool by means of which a human being has been able to accommodate oneself to his experiences in his total environment. Peter Berger (1969) in his book A Rumor of Angels: Modern Society and the Rediscovery of the Supernatural, in defence of religion, says that whatever the situation may have been in the past, today the supernatural as a meaningful reality is absent or remote from the horizons of everyday life of large numbers, very probably the majority, of people in modern societies, who seem to manage to get along without it quite well. Berger was defending individual decision to retain recognition of spiritual realities. In spite of the research of Nottingham and Berger, Prof. Daniel C. Dennett in 2015 theorised that religion retreats and flees whenever human security and well-being rises; human well-being will continue to rise and thus religion is bound to fail in the nearest future. Professor David Voas of University College London Institute of Education in 2016 explained that 'religiosity has been declining for decades, and the decline is driven by the same dynamic of generational change that has driven religious decline across the developed world'. However, religion and secularism have continued to live together for a long time now with neither of them dying out. There are rare studies that have been carried out in recent scholarly discourse to dialogue on the fact that religion and secularism can actually live side by side. Some studies put specifics on the fact that the developments envisaged in contemporary society would one day swallow religion, and humans would become irreligious. Auguste Comte, Herbert Spencer, Emile Durkheim, Ernst Troeltsch, James Frazer, Karl Marx, Sigmund Fraud and Frederick Engels predicted that modernised societies would eventually be secularised to a point where religion would disappear. For example, Sir James Frazer (1959) in his book The Golden Bough notes that humanity in the process of evolution passes through three stages, viz. magic, religion and science. For him, this is the period of science, and religion is declining and would be exterminated. This is the line that this study finds it difficult to agree with.

\section{Theoretical framework}

The lens with which to observe the problem under discussion is the secularisation theory. The secularisation theory according to William and Christiano (1999:214) holds that 'in the face of scientific rationality, religion's influence on all aspects of life - from personal habits to social institutions - is in dramatic decline'. From the family to the society, religion tends to lose her grip on humanity, in terms of his activities. On the importance of this theory, some of the important social dynamics that lie behind religious developments are better understood. These developments may include the high number of people that stop attending religious ceremonies and programmes and the decline in the number of non-prosperity message evangelists, among others. This theory was based on Weber's (1963:384) assertion that religion will not disappear, but instead, there would be a reduction in humanity's dependence on God - religiosity. Steve explains that 'religion can remain an important part of individual beliefs, but he believes that religion has lost its social and political significance' (1995). In politicking and social interaction, religion has lost its control over humans. The theory explains the fact that supernatural explanations would not be used to solve human problems and difficulties.

\section{Auguste Comte's model of beliefs}

Isidore Auguste Marie Francois Xavier Comte was a French philosopher, born in 1798 and died in 1857. Auguste Comte looked at human history and postulates that it is made up of three stages, and he noted that each stage has its own intellectual belief in relation to religion. He was addressing people who felt that religion cannot be neglected by the rising modernisation. He observed that as countries witnessed unprecedented solutions to problems of humanity, people tend to be self-confident in their survival. Comte's three stages of intellectual belief are the theological stage, the metaphysical stage and the positive stage. Birnbaum (2000:494) explains that the order of Comte's view was the development of the sciences - mathematics, astronomy, physics, chemistry, biology and sociology - which reflected the necessities of his mental development. Thus, it could be deciphered that Comte, using his ideology of the happenings in the sciences, came to a conclusion that religion is in a radical and geometrical decline.

In each of these stages, humans give power and the functionality of the contemporary world to forces that are represented at each stage. Comte strikingly notes that in the first stage, that is, the theological stage, 'religious and superstitious beliefs would be dominant' (Birnbaum 2000:494). At this point, humans show total allegiance and humility to God and see him as the sole provider. The human usually consults God in any action to be taken on a daily basis. In the second stage, the metaphysical stage, 'the functioning of the world was attributed to forces of a disembodied and hypothetical kind' (Birnbaum 2000:494). This means that humanity's attention to philosophy and theories begin to increase and religion begins to wane. In the final stage, 'Religious belief would disappear altogether in the final positive stage, in which science alone would dominate human thinking and direct human behaviour' (Birnbaum 2000:494) (see Figure 1). 


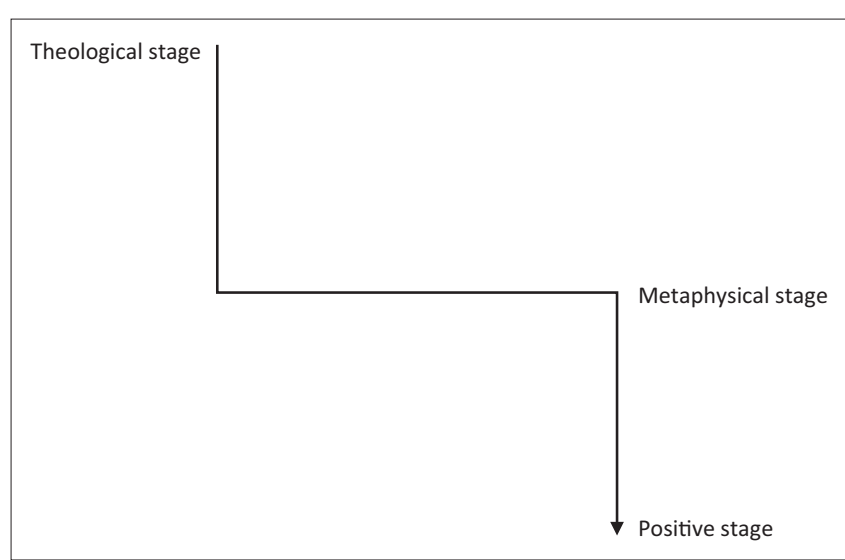

FIGURE 1: A paradigm of Auguste Comte's different set of intellectual beliefs.

Comte's set of intellectual beliefs was a postulation to the eventual demise of religion. Comte, being influenced strongly by Saint-Simon, who at this time was his mentor, developed his ideology of a scientifically directed society. For him, there is no way that secularisation being brought about by scientific innovation could work together with religion, and thus, a conflict must ensue, with religion being overwhelmingly defeated, killed and buried. Comte postulated that the death of the sacred begins with the secularisation of religion which culminates in the positive stage, where religious society becomes a scientifically moving entity.

From the discussion above (see Figure 2), when there is a discovery of a new solution to a particular problem, which hitherto was held sacrosanct by religion, there is a very high tendency for religion to lose its grip on the psychology of the people. Hitherto, the infertility of the soil was held to be caused by a god, but today, improvement in science, seen in the introduction of fertilisers, has brought about improvement in soil fertility and crop residue. Thus, each stage of improvement in science leads to secularism gaining more places in the scheme of things in human society. Fowler et al. (2012:5) explain that in 1905, Max Weber maintained that the rationalisation of society, that is, the development of a rational worldview, and the expansion of knowledge through science would ultimately make belief in the supernatural impossible. At the macro-level, as opposed to the individual level, science would lead to the disenchantment of society, that is, to the loss or devaluation of 'mystery' and the 'supernatural', or the demystification of the society. Webster is saying that religious knowledge and ways of understanding the world, along with notions of divine authority, would largely fade away and disappear completely. It is on this course that Okwueze (2003:128) opines that religion wishes to remain in control of everything, but science makes this wish impossible, and for this reason religion and science are pitched in a mutual, unending conflict as science battles daily to reduce the area controlled by religion by cutting some parts of the unknown into the known. When science charts a new course of knowledge, religion is always threatened and responds in many cases by challenging the new scientific finding or outrightly rejecting it as untrue, misleading, devilish and unacceptable.

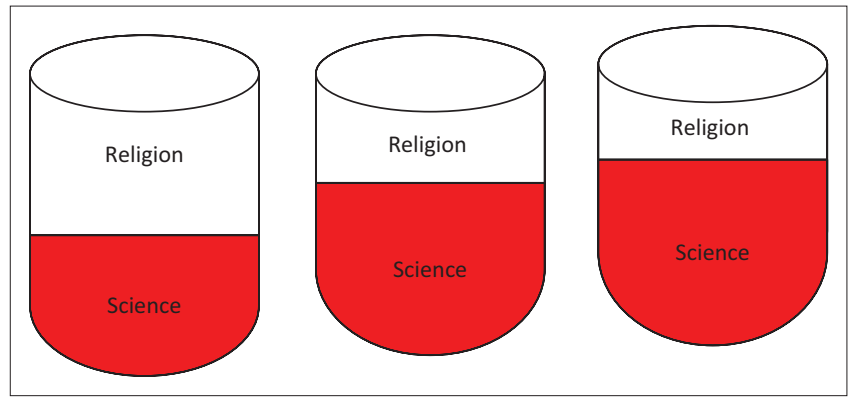

FIGURE 2: The rise in infiltration of religion by secularism caused by improvement in science and technology.

Armstrong explains that the development of modernity led to secularisation, which has marginalised the role of religion in modernity because science and rationality supplant faith in religious beliefs and because the differentiation of institutions largely relegates religion to a private sphere (Armstrong 1993:146).

\section{Secularisation of the sacred}

Secularisation is derived from the Latin word saeculum which means 'worldly'. Zuckerman and Shook (2017) sketches that it was in Christian Latin of medieval times, that saeculum was used for distinguishing this temporal age of the world from the eternal realm of God. Secular means when something is neither religious nor spiritual in its nature. Secularisation 'is a long-term process occurring in human society' (Wilson 1966:276). Beyer (2014:3) explains further that saecula under Christian interpretation came to denote temporary time, the time until the second coming of Christ. St Augustine added an existential dimension by dividing human existence into existence in the City of God, the religious people and the City of Man, indicating people living in the secular reality to be without the guidance of God. This came to denote those living without Christianity as being secular. References to the secular were no longer only to indicate the temporal but now also the existential. Secularism in religion, as a concept, was first postulated by George J. Holyoake in 1850. From his analysis, secularism 'asserts the right to discuss and debate ... opinions regarding the foundations of moral obligation, the existence of God, the immortality of the soul, and the authority of conscience' (Cross 1990:1255). Through secularisation, religion through a historical process loses social and cultural significance. Secularisation offers a globalised world, a world that shares or tries to harmonise cultures of different groups of people. This tends to push religion to the background, because of the fact that the societies which once revered religion, with centrality on the Supreme-Being, are now following the trend of the globalised world and enjoying its accompanying benefits brought about by science and technology. Secularisation, so projected by researchers before 1970, was a thing of sorrow for those who show affinity to religion. It was a period when humanity felt supreme to his life and needs because of humanity's innovation through science and technology.

Taylor (2007) writes that the contemporary period is the west's current age of authenticity which is an individualistic era in which people are encouraged to find their own way or 
do their own thing. The idea that one had to use one's own reason and experience to find God instilled a sense of intellectual autonomy that led some to abandon God altogether. Religion is declining. It is fastly losing its place in the scheme of things, especially in the last two centuries. For Taylor, it is becoming a norm for people to no longer believe in God. However, in 1994, Jose Casanova in his book Public Religions in the Modern World strikingly explains that instead of dying out, religion under secularisation was gaining public acceptance. This thesis of Casanova was represented in three stages (see Figure 3).

According to Casanova (1994), the first stage, which is the stage of differentiation, is encircled with a situation whereby secularisation takes place when non-religious spheres of life become separate from and independent of religion. In the second stage, there is secularisation in terms of the decline of religious beliefs and practices. This is seen when fewer individuals take part in religious activities or hold religious beliefs. In the third stage of secularisation as privatisation, religion stops playing any part in public life and does not even try to influence how politicians or individuals make decisions or choose to live their lives.

Looking at Casanova's opinion, the third stage is heralded with the secularisation of state and the economy. This was a period where humanity exempts religion totally from these two spheres. It should not be seen as if religion was totally dead; instead, these spheres of humanity's livelihood are made independent of religion. Casanova went further to argue that the stage of decline in religious beliefs and practices is 'both normatively flawed and empirically false' (Casanova 1994:330). This notion of the second stage being both normatively flawed and empirically false was refuted by Wilson, who maintains that 'science not only explained many facets of life and the material environment in a way more satisfactory[than religion], but it also provided confirmation of its explanation in practical results' (Wilson 1966:n.p). Douglas (1973:n.p), however, explains that religion also confirms its explanations in practical and non-practical results. He puts:

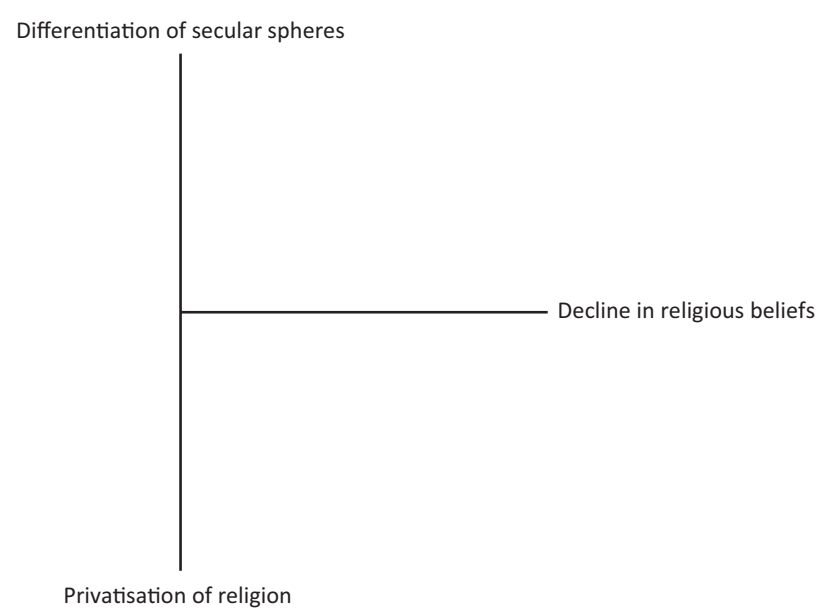

FIGURE 3: Casanova's aspects of secularisation or the distinct moments of secularisation.
The contrast of secular with religious has nothing whatever to do with the contrast of modern with traditional or primitive...the truth is that all varieties of skepticism, materialism and spiritual fervor are to be found in the range of tribal societies.

From Douglas' thesis, all the stages of intellectual belief of Comte have an element of spiritual fervour. Gauchet (1985) reinstates that it is absolutely impossible that, with regard to Christianity, one could say that it has been secularised, because it is by virtue of its own internal developments of a logical unfolding of its own religious world image.

In contemporary times, it could be envisaged that people and in fact societies are willing to change their beliefs because of the existence of a new knowledge. When this era of new knowledge comes, it could be seen as the era of high modernity (Giddens 1991). This era of high modernity deals with the preference of one belief to another when the individual feels that the other belief did not secure the needed social development he needed. The survival of religion is being projected as a central consequence of high modernity.

\section{The 21st century secularised religion}

The 21st century undoubtedly has led to high discoveries making claims and counterclaims. Humanity has been able to bring forward the possibility of solutions to some problems that were hitherto thought to be religiously inclined. These scientific discoveries produced a series of shock in the domain of Christian belief and the shocks have had a powerful effect in the way of undermining religious faith (Stace 1952:84).

Hitherto, it was thought that the movement of celestial bodies (sun, moon, stars, galaxies, etc.) is being caused by God, or a lesser supernatural being; however, through the advent of science, mainly through the activities of Galileo, it was propounded that all uniform bodies will continue their movement unless some force acts on them to stop. Also, the religious saying that anything that is thrown up will come down is an act which is permissible by God; but Isaac Newton, in his explanation of gravitational force, explains that anything that goes up must surely come down (Cordis 2002). Furthermore, religion made humans understand that the sun revolves around the earth, hence making the earth static, but science has been able to lay proof that it is the sun that revolves around the earth. These examples and more produced many claims to which religion a priori was opposed to.

\section{A sacred religion in a secularised world}

The changes happening in today's society undoubtedly have had an impact on all aspects of human life. Religion is no exception. Religion has witnessed changes in its mode of worship, thanksgiving, exhortation and humanity's methods of approaching the Supreme-Being. All these 
developments were caused by modernisation, globalisation and secularisation of the contemporary world.

Religion, humanity's appreciation of the sacred, that is, 'things set out of forbidden' (Durkheim 1912:39-40), has undoubtedly faced changes. This has made scholars and theorists such as Comte to conclude religion will soon die. However, the theory of rationalisation has been postulated to be used to equate the development of religion (sacred) alongside secularism. People like Quentin Atkinson, a psychologist at the University of Auckland, lucidly put that New Zealand, Japan, the UK, Canada, South Korea, the Netherlands, the Czech Republic, Estonia, Germany, France and Uruguay (where the majority of citizens have European roots) are all places where religion was important just a century or so ago, but that now report some of the lowest belief rates in the world. 'These countries feature strong educational and social security systems, and low inequality and are all relatively wealthy' (Nuwer 2014). Norris and Inglehart (2004:374) observe: 'the case for human security (increasing while societies develop) as the most important explanation of the salience of religious values, that in their turn determine religious participation that in its turn causes religious political activism'. In addition, as societies differ by religious culture, different religious beliefs survive in different societies. The reason for this is because 'Basically, people are less scared about what might befall them' (Nuwer 2014). Thus, Norris and Inglehart (2008) write:

the people of poorer societies and more vulnerable sectors of society will usually regard religion as far more important than more those of affluent nations and people living in states with generous welfare safety-nets and with deeper reservoirs of household savings, private insurance, and investments, which usually experience greater freedom from fear in their lives. Levels of social and individual security are expected to lead towards predictable probabilistic variations in religious values (reflecting the vital importance of religion in people's lives), although at the same time residual religious beliefs, ritualistic practices and institutions will continue to bear a strong imprint stamped by each specific type of faith. (pp. 5-6)

Religion is only appreciated by the poor communities and underdeveloped countries of the world. Religion strives where people are in abject poverty and under constant attack. Hence, if all societies achieve self-sufficiency and become developed nations, religion would eventually depreciate and be decimated. For Nietzsche (1974), humanity considers that because of problems of life, God is nowhere to be found, and hence, religion also died along with God. Thus, he explains:

God is dead. God remains dead. And we have killed him. How shall we comfort ourselves, the murderers of all murderers? What was holiest and mightiest of all that the world has yet owned has bled to death under our knives: who will wipe this blood off us? What water is there for us to clean ourselves? What festivals of atonement, what sacred games shall we have to invent? Is not the greatness of this deed too great for us? Must we ourselves not become gods simply to appear worthy of it? (pp. 181-182)
Providing succour on the inevitability of religion in the face of science, Dietrich (1928) strikingly explains:

Science is only man thinking - one of dysfunctional activities of humanity, as religion is another of his functional activities. Instead of being a thing it is only a method of dealing with things. It is the way - and I believe the only way - of finding the truth. I do not believe that any man ever discovered any truth, or ever will, except by the scientific method. (p. 165)

Religion deals with the divine. Religion is humanity's attitude towards God and the relation in which he stands to the universe or to the powers or power that he recognises as outside himself and to a large extent controlling his destiny. Of course, this thought is accompanied by appropriate emotions, and the thought and emotion will find external expression in fitting rites and courses of conduct. It could be agreed that decline in religion does not mean disappearance. Although Sean Carroll, a theoretical cosmologist at the California Institute of Technology, in Mattson (2014:151), writes that science will ultimately arrive at a complete understanding of the universe that leaves no grounds for God whatsoever, Newton (1713) as cited in Dobson (2016) explains as a counter thus:

This most beautiful system of the sun, planets, and comets, could only proceed from the counsel and dominion of an intelligent and powerful Being. And if the fixed stars are the centers of other like systems, these, being formed by the like wise counsel, must be all subject to the dominion of One; especially since the light of the fixed stars is of the same nature with the light of the sun, and from every system light passes into all the other systems: and lest the systems of the fixed stars should, by their gravity, fall on each other mutually, he hath placed those systems at immense distances one from another ... 'This Being governs all things, not as the soul of the world, but as Lord over all; and on account of his dominion he is wont to be called Lord God pantokrator, or Universal Ruler ... And from his true dominion it follows that the true God is a living, intelligent, and powerful Being; and, from his other perfections, that he is supreme, or most perfect ...'. It is allowed by all that the Supreme God exists necessarily; and by the same necessity he exists always, and everywhere. (p. 291)

It could be rarely deciphered that the religiosity of a religious society can be properly deciphered without the use of secularism to measure its efficiency. For example, one feature required of a religious person is the act of being a responsible person. In the same vein, the secularised society also requires being responsible as the main characteristic, so as to be able to meet up with its demanding developmental progressions. Succinctly, Udokporo, Okemiri and Olaomo (2012:57) sketch that 'God rewards those who are responsible. Being responsible usually leads to reliability'. It is also worthy of mention to note that, while science observes and investigates, religion interprets; science gives humanity knowledge, which is power, while religion gives humanity wisdom, which is control; science deals mainly with facts, religion deals mainly with values; hence, they are not rivals but instead complement each other (Okwueze 2003:122).

What is being observed between religion and science is what happens between goods that are complementary. They both 
seek for relevance. For example, a buyer in a market has 20 dollars and he needed to buy a wooden chair and a plastic chair; hence, he went to the market, he succeeds in buying a wooden chair worth 19 dollars, and he buys just a plastic chair for a dollar, this might make the demand for plastic chair less relevant when compared to wooden chair. This is what is seen among religion and secularism. The demand for one makes the other less significant and less desirable. It is not that the other is better than it, but the demand that is being placed on one at the expense of the other makes it look insignificant. Consequently, it should be noted that the pillar and post nature of religion and science makes for a very fine society. For the one cannot survive effectively without the other; hence, religion and science are needed for even development of human society.

Beyer (1994) in his book Religion and Globalization argues that religion attempts to be more ecumenical as it tries to bring together different faiths and beliefs. Instead of emphasising difference, it emphasises common values or beliefs that are, or it believes should be, shared globally. Beyer (1994) further reveals that the rise of globalisation will not lead to the demise of religion. Bauman (1992) defines that religion would continue to gain ground, in that 'religious revival results from the problem faced by individuals'. Humanity's problem must surely continue to drag him to seek the help of the Supreme-Being in aspects of his life where he hitherto thought he has conquered. For religion, as part of culture is 'man's response to his awareness of a supreme being who is his creator' (Udoidem 2002:124), and this awareness is seen in his resorts to the help of God when science and technology cannot come to his help. This will continue to be a circle because, 'global flow of information and ideas make it harder for people to maintain a fixed and unchanging set of beliefs' (Lyon 2000). Consequently, there it is observable that there is the rise of 'spirituality' in the 20th century (Carrette \& King 2005).

\section{Conclusion}

Secularism and religion are undoubtedly complementary in their approach to human existence. Religion needs secularism for a balanced philosophy of human problems. Religion has not disappeared and is unlikely to do so. Thus, traditional secularisation models which anticipated the decimation of religion need more update. The thesis of Comte, with regard to the eventual death of religion, should be taken with a pinch of salt as religion has for a time now continued to provide answers to questions which secularisation of other facets of humanity's livelihood could not solve. The world as a whole now has more people with traditional religious views than ever before, and they constitute a growing proportion of the world's population. Also, August Comte and other secular theorists fail to take other rich and poor countries as part of his data collection; instead, they were using countries like the United States and other developed nations. Norris and Inglehart (2004) corroborate that religion survives in most countries of the world such as poorer nations, and in failed states, facing personal survivalthreatening risks and fear of exposure to physical, societal and personal risks drive religiosity. Conversely, a systematic erosion of religious practices, values and beliefs has occurred among the more prosperous strata in rich nations. Religion, just like other aspects of culture, is susceptible to change in some of its features and not a change to an entirely new phenomenon, hence its death. In view of the fundamentally religious nature of evolution, it is not surprising to find that most world religions are themselves based on evolution (Morris 1982). Human society is complex. Religion, a form of civilisation, is 'like living organisms which go through recurrent cycles of genesis, growth, and decline' (Toynbee \& Ikeda 1989:309). This decline is perhaps what Comte termed as 'the death of religion'. Worship, prayers and the divine source of revelation cannot be fully known; hence, religion would continue to survive. Religion interacts with other social institutions - marriage, customs, norms, occupation, politics - thus, its survival is imminent. To decimate religion in place of secularism is like taking a hen off its eggs and expecting the sun to hatch them into chicks.

\section{Acknowledgements Competing interests}

The authors declare that they have no financial or personal relationships which may have inappropriately influenced them in writing this article.

\section{Authors' contribution}

A.B.O. and F.C.U. contributed immensely to the production of this research work. These contributions include the search for classic reference materials, organisation and writing of the research work, and the formatting of the article to suit the standard of HTS.

\section{References}

Armstrong, K., 1993, The political anatomy of the body, Cambridge University Press, Cambridge.

Bauman, Z., 1992, Intimations of post modernity, Routledge, London.

Berger, P.A., 1969, Rumor of angels: Modern society and the rediscovery of the supernatural, Doubleday \& Co., Garden City, NY.

Bergunder, M., 2014, 'What is religion? The unexplained subject matter of religious studies', Method and Theory in the Study of Religion 26, 246-286. https://doi. org/10.1163/15700682-12341320

Beyer, P., 1994, Religion and globalization, Sage, London.

Beyers, J., 2014, 'The church and the secular: The effect of the post-secular on Christianity', HTS Teologiese Studies/Theological Studies 70(1), 1-12. https://doi. org/10.4102/hts.v70i1.2605

Birnbaum, N., 2000, 'Comte', in P. Bayer et al. (eds.), The Encyclopedia Americana, Grolier Incorporated, vol. 7, p. 474, New York Danbury, CT.

Bruce, S., 1996, Religion in the modern world: From cathedrals to cults, Oxford University Press, Oxford.

Carrette, J. \& King, R., 2005, Selling spirituality. The silent takeover of religion, Routledge, London.

Carroll, S., 2014, The big picture: On the origin of life, meaning and the world itself, in Mattson, R., 2014, Faith is like skydiving: And other memorable images for dialogue with seekers and skeptic, Downers Grove, DuPage County, Illinois, IL.

Casanova, J., 1994, Public relations in the modern world, University of Chicago, Chicago, IL.

Comte, A., 1896, The positive philosophy, Bell \& Sons, London.

Cordis, 2002, 'Sir Isaac Newton', 02 October, viewed 21 November 2017, from http:// cordis.europa.eu/scienceweek/inspiration01.htm 
Crabtree, V., 2016, What is religion? How do you define religion?, viewed 12 November 2017, from http://www.humanreligions.info/what_is_religion.html

Cross, F.L. (ed.), 1990, The Oxford Dictionary of the Christian church, Oxford University Press, Oxford.

Dobson, G., 2016, A chaos of delight: science, religion and myth and the shaping of Western thought, Routledge, New York.

Dennett, D., 2015, 'Why the future of religion is bleak', The Wall Street Journal, 26 April, viewed 21 March 2017, from https://www.wsj.com/articles/why-thefuture-of-religion-is-bleak-1430104785

Dietrich, J., 1928, Will science destroy religion? Minneapolis, MN.

Douglas, M., 1973, Natural symbols: Explorations in cosmology, Penguin Books, London.

Durkheim, E., 1912, The elementary forms of religious life, The Free Press, New York.

Fowler, M., Kirkham, S., Sawatzky, R. \& Taylor, E.J., 2012, Religion, religious ethics and nursing, Springer Publishing Company, New York.

Frazer, J.G., 1959, The new golden bough, Criterion Books, New York.

Gauchet, M., 1985, Le Désenchantement du Monde. Une Histoire Politique de la Religion, Gallimard, Paris.

Giddens, A., 1991, Modernity and self identity: Self and society in the late modern age, Polity Press, Cambridge, in Holborn, M. \& Haralambos, M., 2004, Sociology themes and perspective, Harpercollins Publication Limited, London.

Loos, A. (transl.), 2004, The essence of religion, Prometheus Books, Amherst, NY.

Lyon, D., 2000, Jesus in Disneyland: Religion in postmodern times, Polity Press, Cambridge.

Mbiti, J., 1969, African religions and philosophy, Heinemann, London.

Morris, H., 1982, Evolution is religion, not science, viewed 23 July 2018, from http:// www.icr.org/article/evolution-religion-not-science/

Nietzsche, F., 1974, The gay science, W. Kaufmann (ed.), Vintage, New York. (Original work published in 1882, 1887).
Norris, P. \& Inglehart, R., 2004, Sacred and secular. Religion and politics worldwide, Cambridge University Press, New York.

Norris, P. \& Inglehart, R., 2008, 'Existential security and the gender gap in religious values', 10 February, viewed 23 November 2017, from https://sites. hks. harvard. edu/fs/pnorris/Acrobat/SSRC $\% 20$ The $\% 20$ gender $\% 20$ gap $\% 20$ in $\% 20$ religiosity $\%$ 20 Norris $\% 20$ and $\% 2$ Inglehart $\% 20 \% 233$.pdf

Nottingham, E.K., 1968, Religion and society, Random House, New York.

Nuwer, R., 2014, 'Will religion ever disappear?', 19 December, viewed 25 April 2017 from http://www.bbc.com/future/story/20141219-will-religion-ever-disappear

Okwueze, M., 2003, Ethics, religion, \& society, Prize Publishers, Nsukka.

Stace, W.T., 1952, Religion and modern mind, Lippincott Press, Philadelphia, PA.

Steve, B., 1995, Religion in modern Britain, Oxford University Press, Oxford.

Taylor, C., 2007, A secular age, Harvard University Press, New York.

Toynbee, A. \& Ikeda, D., 1989, Choose life: A dialogue, Oxford University Press, Great Britain.

Udoidem, S.I., 2002, 'Religion in the political life of Nigeria: A survey of religiousrelated crises in Nigeria since independence', in E.U.M. Igbo \& E.E. Anugwom (eds.), Social change and social problems a Nigerian perspective, pp. 16-20, AP Express Publishing Company, Nsukka.

Udokporo, L.O., Okemiri, C.O. \& Olaomo, Y.A., 2012, Melrose Christian religious studies, Melrose Books and Publishing Limited, Ogun State.

Voas, D., 2016, 'American devotion to religion is waning according to new study', UCL News, 10 March, viewed 25 April 2017, from https://www.ucl.ac.uk/news/newsarticles/0316/100316-American-devotion-to-religion-is-waning

Weber, M., 1963, The sociology of religion, Beacon Press, Boston, MA.

William, S. \& Christiano, K., 1999, 'Secularization theory: The course of a concept', Sociology of Religion 60, 3.

Wilson, B., 1966, Religion in a secular society, C.A. Watts, London.

Zuckerman, P. \& Shook, J. (eds.), 2017, 'Introduction: The study of secularism', in The Oxford handbook of secularism, pp. 71-82, Oxford University Press, Oxford. 